\title{
Minimization of excess sludge production for biological wastewater treatment
}

\author{
Yuansong Wei ${ }^{\mathrm{a}, *}$, Renze T. Van Houten ${ }^{\mathrm{b}}$, Arjan R. Borger ${ }^{\mathrm{b}}$, Dick H. Eikelboom ${ }^{\mathrm{b}}$, \\ Yaobo Fan ${ }^{\mathrm{a}}$ \\ ${ }^{a}$ Department of Water Pollution Control Technology, Research Centre for Eco-Environmental Sciences, Chinese Academy of Sciences. \\ P.O. Box 2871, Beijing 100085, People's Republic of China \\ ${ }^{\mathrm{b}}$ Department of Environmental Biotechnology, TNO Environment, Energy and Process Innovation. P.O. Box 342, 7300 AH Apeldoorn,
} The Netherlands

Received 15 May 2002; received in revised form 17 July 2003; accepted 24 July 2003

\begin{abstract}
Excess sludge treatment and disposal currently represents a rising challenge for wastewater treatment plants (WWTPs) due to economic, environmental and regulation factors. There is therefore considerable impetus to explore and develop strategies and technologies for reducing excess sludge production in biological wastewater treatment processes. This paper reviews current strategies for reducing sludge production based on these mechanisms: lysis-cryptic growth, uncoupling metabolism, maintenance metabolism, and predation on bacteria. The strategies for sludge reduction should be evaluated and chosen for practical application using costs analysis and assessment of environmental impact. High costs still limit technologies of sludge ozonation-cryptic growth and membrane bioreactor from spreading application in full-scale WWTPs. Bioacclimation and harmful to environment are major bottlenecks for chemical uncoupler in practical application. Sludge reduction induced by oligochaetes may present a cost-effective way for WWTPs if unstable worm growth is solved. Employing any strategy for reducing sludge production may have an impact on microbial community in biological wastewater treatment processes. This impact may influence the sludge characteristics and the quality of effluent.
\end{abstract}

(C) 2003 Elsevier Ltd. All rights reserved.

Keywords: Excess sludge; Minimization of sludge production; Sludge reduction; Wastewater treatment

\section{Introduction}

Biological wastewater treatment involves the transformation of dissolved and suspended organic contaminants to biomass and evolved gases $\left(\mathrm{CO}_{2}, \mathrm{CH}_{4}, \mathrm{~N}_{2}\right.$ and $\mathrm{SO}_{2}$ ) [1]. The activated sludge process is the most widely used biological wastewater treatment for both domestic and industrial plants in the world. It is more intensive than fixed film processes and can treat up to 10 times more wastewater per unit reactor volume but does have higher operating costs [2]. One of the drawbacks of

\footnotetext{
*Corresponding author. Tel./fax: + 86-10-62849108.

E-mail address: ys_wei@yahoo.com (Y. Wei).
}

conventional activated sludge (CAS) processes is high sludge production. In activated sludge plants the sludge yield coefficient is typically 0.5 [3]. Currently, production of excess sludge is one of the most serious challenges in biological wastewater treatment. Treatment and disposal of sewage sludge from wastewater treatment plants (WWTPs) accounts for about half, even up to $60 \%$, of the total cost of wastewater treatment [4,5]. In 1991/1992, member states of the European Union (EU) operated at 40,300 WWTPs that produced 6.5 million tonnes of dry solids per year. As a result of the Urban Waste Water Treatment Directive (UWWTD) which requires more extensive wastewater treatment and an end to sea disposal of sewage sludge, 
the sewage sludge production in EU is estimated to increase by at least $50 \%$ by the end of 2005 , producing 10.1 million tonnes of dry solids per year. Main alternative methods for sludge disposal in EU are landfill, land application and incineration, accounting for nearly $90 \%$ of total sludge production in EU [4]. Land application of sewage sludge is restricted to prevent health risks to man and livestock due to potentially toxic elements in the sewage sludge, i.e. heavy metals, pathogens, and persist organic pollutants. Declines in available land space, coupled with increasing stringent regulations governing the design and operation of new landfills, have caused the cost of siting, building, and operating new landfills to rise sharply. Generally, incineration is the final option for sewage sludge disposal. The process generates ash, which tends to go to landfill as it cannot be disposed elsewhere due to the high heavy metals content and general toxicity. Hence, the current legal constraints, the rising costs and public sensitivity of sewage sludge disposal have provided considerable impetus to explore and develop strategies and technologies for minimization of sludge production.

An ideal way to solve sludge-associated problems is to reduce sludge production in the wastewater treatment rather than the post-treatment of the sludge produced. Microbial metabolism liberates a portion of the carbon from organic substrates in respiration and assimilates a portion into biomass. To reduce the production of biomass, wastewater processes must be engineered such that substrate is diverted from assimilation for biosynthesis to fuel exothermic, non-growth activities. Different strategies are currently developed for sludge reduction in an engineering way based on these mechanisms: lysiscryptic growth, uncoupling metabolism, maintenance metabolism, and predation on bacteria [1,6-8]. This paper gives an overview of these strategies currently applied and studied for minimization of sludge production in biological wastewater treatment in order to seek an optimal solution.

\section{Lysis-cryptic growth}

Cell lysis will release cell contents into the medium, thus providing an autochthonous substrate that contributes to the organic loading. This organic autochthonous substrate is reused in microbial metabolism and a portion of the carbon is liberated as products of respiration, and then results in a reduced overall biomass production. The biomass growth that subsequently occurs on this autochthonous substrate cannot be distinguished from growth on the original organic substrate, and is therefore termed as cryptic growth [9].

There are two stages in lysis-cryptic growth: lysis and biodegradation. The rate-limiting step of lysis-cryptic growth is the lysis stage, and an increase of the lysis efficiency can therefore lead to an overall reduction of sludge production. Several methods have been applied for sludge disintegration so far: (i) thermal treatment in the temperature range from $40^{\circ} \mathrm{C}$ to $180^{\circ} \mathrm{C}[10,11]$, (ii) chemical treatment using acids or alkali [12], (iii) mechanical disintegration using ultrasounds, mills, and homogenizers [13-20], (iv) freezing and thawing [21], (v) biological hydrolysis with enzyme addition [22], (vi) advanced oxidation processes such as wet air oxidation, using $\mathrm{H}_{2} \mathrm{O}_{2}$ and ozone [23-26], and (vii) combination ways such as thermo-chemical treatment [27-29], combination of alkaline and ultrasonic treatment [30]. But the comparison and evaluation of these processes for sludge lysis is not considered in this paper. Sludge lysis and subsequently cryptic growth could be promoted by physical, chemical and combined ways in order to reduce sludge production, such as ozonation [31-38], chlorination [39,40], integration of thermal/ ultrasonic treatment and membrane [41,42], integration of alkaline and heat treatment [43-45], and increase of oxygen concentration [46]. Table 1 summarizes sludge reduction under lysis-cryptic growth condition. Among these techniques on the basis of lysis-cryptic growth sludge ozonation for reducing sludge production has been successfully applied in practice.

\subsection{Ozonation}

Yasui and Shibata [31] developed a new process for reducing excess sludge production in the activated sludge process. The process consists of a sludge ozonation stage and a biodegradation stage, in which a fraction of recycled sludge passes through the ozonation unit and then the treated sludge is decomposed in the subsequent biological treatment. The ozonation of sludge results in both solubilization (due to disintegration of suspended solids) and mineralization (due to oxidation of soluble organic matter), and the recycling of solubilized sludge into the aeration tank will induce cryptic growth. Throughout the operation periods of full-scale plants with sludge ozonation process for treating municipal wastewater and industrial wastewater, respectively, no excess sludge was withdrawn and no significant accumulation of inorganic solids occurred in the aeration tank at optimal ozone dose rates. The operation costs of this process were estimated to be lower than those of conventional sludge treatment process, including sludge dewatering and disposal [32,33]. Different from their continuous ozonation way [31-33], Kamiya and Hirotsuji [34] therefore developed a new system combining both biological treatment and intermittent ozonation to reduce the excess sludge production with fewer amounts of ozone and simultaneously control the sludge bulking. Results of their lab-scale experiment treating synthetic sewage indicated that the intermittent ozonation not only 
Table 1

Literature data of lysis-cryptic growth for reducing excess sludge production

\begin{tabular}{|c|c|c|c|}
\hline Operation conditions & $\begin{array}{l}\text { Sludge } \\
\text { reduction }(\%)\end{array}$ & Effluent quality & References \\
\hline \multicolumn{4}{|l|}{ Ozonation } \\
\hline $\begin{array}{l}\text { Full scale; } 550 \mathrm{~kg} \mathrm{BOD} / \mathrm{d} \text { of industrial wastewater, continuous } \\
\text { ozonation at } 0.05 \mathrm{~g} \mathrm{O}_{3} / \mathrm{g} \mathrm{SS}\end{array}$ & 100 & Increase of TOC & {$[32]$} \\
\hline $\begin{array}{l}\text { Full scale, } 450 \mathrm{~m}^{3} / \mathrm{d} \text { of municipal wastewater, continuous } \\
\text { ozonation at } 0.02 \mathrm{~g} \mathrm{O}_{3} / \mathrm{g} \mathrm{SS}\end{array}$ & 100 & Slight increase of BOD & {$[33]$} \\
\hline $\begin{array}{l}\text { Lab scale, synthetic sewage, intermittent ozonation at } \\
11 \mathrm{mg} \mathrm{O}_{3} / \mathrm{mg} \mathrm{SS} \text { (aeration tank)d }\end{array}$ & 50 & Nearly unaffected & {$[34]$} \\
\hline \multicolumn{4}{|l|}{ Chlorination } \\
\hline Bench scale, $20^{\circ} \mathrm{C}$, synthetic wastewater, $0.066 \mathrm{~g} \mathrm{CI}_{2} / \mathrm{g} \mathrm{MLSS}$ & 65 & Significant increase of SCOD & {$[40]$} \\
\hline \multicolumn{4}{|l|}{ Thermal or thermo-chemical treatment } \\
\hline $\begin{array}{l}\text { Lab scale }\left(90^{\circ} \mathrm{C} \text { for } 3 \mathrm{~h}\right) \text {; membrane bioreactor; synthetic } \\
\text { wastewater }\end{array}$ & 60 & Unaffected & {$[41]$} \\
\hline Lab scale $\left(60^{\circ} \mathrm{C}\right.$ for $\left.20 \mathrm{~min}, \mathrm{pH} 10\right)$; synthetic wastewater & 37 & - & {$[45]$} \\
\hline \multicolumn{4}{|l|}{ Increasing DO } \\
\hline Lab scale; synthetic wastewater; increasing DO from 2 to $6 \mathrm{mg} / 1$ & 25 & - & [46] \\
\hline
\end{tabular}

reduced sludge production by $50 \%$ with only $30 \%$ of the ozone dose required for continuous ozonation, and but also improved the sludge settling characteristics. Similar research showed that the intermittent ozonation was preferred over the continuous ozonation due to increased solubilization rates [35-38]. Although sludge ozonation caused TOC slight increase in the effluent, an investigation [47] showed that the organic matter in the effluent through sludge ozonation was mainly composed of proteins and sugars moieties, which should be harmless for the environment. Chlorine was used instead of ozone because the cost of chlorination is cheaper $[39,40]$. The chlorination of sludge at a chlorine dose of $0.066 \mathrm{~g} \mathrm{Cl}_{2} / \mathrm{g} \mathrm{MLSS}$ reduced the excess sludge production by $65 \%$, but its principal disadvantages are the formation of trihalomethanes (THMs), bad sludge settleability and significant increase of soluble chemical oxygen demand (SCOD) in the effluent.

\subsection{Other lysis techniques}

Most biological wastewater treatment processes are temperature sensitive, and thus increasing process temperature is effective for reducing sludge production. Low temperature operation can lead to the increase of sludge production, i.e. the sludge production at $8^{\circ} \mathrm{C}$ in the activated sludge process was increased by about $12-20 \%$ compared with that at $20^{\circ} \mathrm{C}$ [48]. The possible explanation of higher sludge production at low temperature is a net accumulation of cell protoplasm within flocs in the form of COD because the hydrolysis of the organisms is the reaction rate-controlling step of the endogenous respiration [49,50]. A side-stream membrane bioreactor (MBR) treating synthetic wastewater by Pseudomonas fluorescens, coupled with a continuous sludge thermal treatment system, was operated for reducing excess sludge production [41]. About $60 \%$ of sludge reduction was achieved when the returned sludge passed through a thermal treatment loop $\left(90^{\circ} \mathrm{C}\right.$ for $\left.3 \mathrm{~h}\right)$. High temperatures can also be combined with acid or alkaline treatment to reduce or condition excess sludge. Different cell lysis techniques (thermal, combination of thermal and alkaline or acid) were then compared with break Alcaligenes eutrophus and wasted activated sludge $[44,45]$. Their results showed that alkaline treatment by $\mathrm{NaOH}$ addition combined with thermal treatment $(\mathrm{pH}$ $10,60^{\circ} \mathrm{C}$ for $20 \mathrm{~min}$ ) was the most efficient process to induce cell lysis and produce biodegradable lysates. The coupling of this lysis system to a biological wastewater treatment bioreactor allowed a $37 \%$ reduction in the excess sludge production compared with the CAS process. Using thermal or thermo-chemical treatment corrosion is the major problem, thus high-grade materials are required. The costs for spare parts and maintenance constitute a large part of the total running costs of the treatment. Odor problem is another major drawback for the thermal treatment [51].

Yoon and Kim [42] used a membrane bioreactorsludge disintegration system (MBR-SD) for reducing sludge production. In this system, parts of sludge from aeration tank of MBR was disintegrated with a sonicater and then supplied to the MBR as a feed solution. The MLSS in the aeration tank could be maintained at about $7.5 \mathrm{~g} / 1$, while that of the conventional MBR increased 
from 7.0 to $13.7 \mathrm{~g} / 1$ during 28 days. Due to a disintegration system introduced in MBR, the actual reaction parameters could be quite different from those in the conventional MBR or activated sludge processes. A mathematical model for the MBR-SD system was therefore developed by incorporating a sludge disintegration term into the CAS model [52]. In this model, a new definition of $F / M$ ratio for the MBR-SD system was suggested to evaluate its actual organic loading rate, and the actual $F / M$ ratio was much higher than the apparent $F / M$ ratio in the MBR-SD.

Abbassi et al. [46] investigated the ability for minimization of excess sludge production by mainly optimizing the oxygen concentration in the activated sludge flocs. Their results showed that a rise of the dissolved oxygen (DO) concentration from 2 to $6 \mathrm{mg} / \mathrm{l}$ led to about $25 \%$ sludge reduction at the sludge loading of $1.7 \mathrm{mg} \mathrm{BOD}_{5} /(\mathrm{mg} \mathrm{MLSS} \mathrm{d})$. The increase of the DO in the bulk liquid leads to a deep diffusion of oxygen, which subsequently causes an enlargement of the aerobic volume inside the flocs. As a result, the hydrolysed microorganisms in the floc matrix can be degraded and thus sludge quantity is reduced. In CAS processes the oxygen transfer yields range from 0.6 to $4.2 \mathrm{~kg} \mathrm{O}_{2} / \mathrm{kW} \mathrm{h}$ depending on the methods of aeration, and aeration typically accounts for more than $50 \%$ of the total energy consumption [1]. Increasing DO in bulk liquid results in sharp increase of the total oxygen demand and subsequently raises the aeration costs.

Overall, the lysis stage is the key step in the strategy of lysis-cryptic growth for sludge reduction. The efficiency of sludge lysis techniques should be evaluated according to both the ratio of the soluble COD release over total COD and the biodegradability of lysates. Inducing sludge lysis requires additional capital costs and operational costs. However, none of the developed processes based on thermal or thermo-chemical treatment for sludge hydrolysis has been successfully commercialized because of costs involved and poor-quality product, such as Porteous, Zimpro, Synox, Protox and Krepro $[53,54]$. Sludge ozonation for reducing excess sludge production has been successfully applied in full-scale industrial and municipal wastewater treatment so far, and further research is needed for the treatment of wasted ozone gas and reducing costs involved sludge ozonation. In addition, the combination of MBR and sludge disintegration techniques may provide a good way for sludge reduction based on the lysis-cryptic growth metabolism.

\section{Uncoupling metabolism}

Bacteria have complex metabolic pathways to control growth, replication and other processes. Catabolism is the reaction series that reduces the complexity of organic compounds produces the free energy. Anabolic paths involve the use of free energy to build the molecules required by cell. Energy transfer between these paths is in the form of adenosine triphosphate (ATP). For most of aerobic bacteria, ATP is generated by oxidative phosphorylation, in which process electrons are transported through the electron transport system from an electron donor (substrate) to a final electron acceptor $\left(\mathrm{O}_{2}\right)$. Bacterial anabolism is coupled to catabolism of substrate through rate limiting respiration [55]. However, uncoupled metabolism would occur if respiratory control did not exist and instead the biosynthetic processes were rate limiting. Therefore, excess free energy would be directed away from anabolism so that the production of biomass can be reduced. Uncoupled metabolism is observed under some conditions, such as in the presence of inhibitory compounds, heavy metals, excess energy source, abnormal temperatures, and limitation of nutrients $[8,56]$. The uncoupling approach is to increase the discrepancy of energy (ATP) level between catabolism and anabolism so that energy supply to anabolism is limited. As a result, the observed growth yield of biomass is declined accordingly when the energy uncoupling occurs. Dissipating energy for anabolism without reducing the removal rates of organic pollutants in biological wastewater treatment may therefore provide a direct mechanism for reducing sludge production.

\subsection{Chemical uncoupler}

Uncoupling is the inability of chemosmotic oxidative phosphorylation to generate the maximum theoretical amount of metabolic energy in the form of ATP, which is also redefined as "uncoupled oxidative phosphorylation" to differentiate it from other mechanisms of uncoupling metabolism [57]. Substrate oxidation creates a proton motive force across the intracellular cytoplasm membrane and this provides the driving force for the oxidative phosphorylation. Oxidative phosphorylation can be effectively uncoupled by the addition of organic protonophores, which carry protons through cells' intracellular cytoplasm membrane thus dissipating the driving force. Recently, many researchers focused on sludge reduction induced by chemical uncouplers, such as 2,4-dinitrophenol ( $d \mathrm{NP})$, para-nitrophenol ( $p \mathrm{NP})$, pentachlorophenol (PCP) and 3,3',4',5-tetrachlorosalicylanilide (TCS) [58-66]. One of the first oxidative uncouplers to be studied was 2,4-dinitrophenol $(d \mathrm{NP})$ in 1948 by Loomis and Lipmann [58]. Table 2 lists effect of some chemical uncouplers on reducing sludge production, and the dose of TCS required for achieving similar sludge reduction is the least compared with other four chemical uncouplers ( $p \mathrm{NP}, d \mathrm{NP}, \mathrm{TCP}, m \mathrm{CP})$.

Several chlorinated and nitrated phenols and benzoates were tested for their short-term effects on cell yield, 
Table 2

Literature data of chemical uncouplers for reducing excess sludge production

\begin{tabular}{|c|c|c|c|}
\hline Chemical uncouplers and operation conditions & $\begin{array}{l}\text { Sludge } \\
\text { reduction }(\%)\end{array}$ & COD removal $(\%)$ & Ref. \\
\hline \multicolumn{4}{|l|}{ Para-nitrophenol ( $p \mathrm{NP})$} \\
\hline $\begin{array}{l}30^{\circ} \mathrm{C}, \mathrm{pH}=6.2 / 7.0 \text {, continuous mono-culture of } P \text {. putida, continuous } \\
\text { addition of } 100 \mathrm{mg} p \mathrm{NP} / 1\end{array}$ & $62-77$ & - & {$[60]$} \\
\hline $\begin{array}{l}20 \pm 1^{\circ} \mathrm{C}, \mathrm{pH}=7.7 \pm 0.3 \text {, continuous activated sludge culture, continuous } \\
\text { addition of } 100 \mathrm{mg} p \mathrm{NP} / 1 \text {, dilution rate }=0.29 \mathrm{~h}^{-1} \text {, sludge discharging } \\
\text { rate }=0.02 \mathrm{l} / \mathrm{h}, \mathrm{MLSS}=0.71 \mathrm{~g} / \mathrm{l}\end{array}$ & 49 & Decreased by 25 & {$[61]$} \\
\hline \multicolumn{4}{|l|}{ 2,4-dinitrophenol $(d \mathrm{NP})$} \\
\hline $\begin{array}{l}20^{\circ} \mathrm{C}, \mathrm{pH}=7, \text { continuous activated sludge culture, continuous addition of } \\
35 \mathrm{mg} d \mathrm{NP} / 1, \mathrm{MLSS}=2.5 \mathrm{~g} / 1, \mathrm{SRT}=1.5 \mathrm{~d}, \mathrm{HRT}=5.5 \mathrm{~h}\end{array}$ & $0.30^{\mathrm{a}}$ & Decreased by 3.7 & {$[62]$} \\
\hline \multicolumn{4}{|l|}{ 2,4,5-trichlorophenol (TCP) } \\
\hline $\begin{array}{l}21^{\circ} \mathrm{C}, \mathrm{pH}=7, \text { continuous activated sludge culture, continuous addition of } \\
2-2.5 \mathrm{mg} \mathrm{TCP} / 1, \mathrm{VSS} / \mathrm{TSS}=0.83, \mathrm{SRT}=5.0 \mathrm{~d}, \mathrm{HRT}=3.5 \mathrm{~h}\end{array}$ & 50 & - & {$[59]$} \\
\hline \multicolumn{4}{|l|}{ 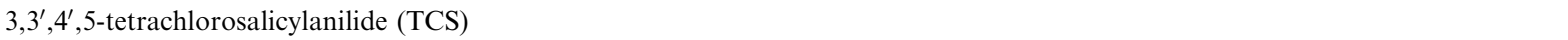 } \\
\hline $\begin{array}{l}20^{\circ} \mathrm{C}, \mathrm{pH}=7 \text {, continuous activated sludge culture, addition of } 0.8-1.0 \mathrm{mg} \\
\mathrm{TCS} / 1 \text { once per day, } \mathrm{MLSS}=2.0 \mathrm{~g} / 1, \mathrm{SRT}=7 \mathrm{~d}, \mathrm{HRT}=8 \mathrm{~h} .\end{array}$ & 40 & Nearly unaffected & {$[63,64]$} \\
\hline \multicolumn{4}{|l|}{$m$-chlorophenol $(m \mathrm{CP})$} \\
\hline $25 \pm 1^{\circ} \mathrm{C}, \mathrm{pH}=7.0$, batch activated sludge culture, addition of $20 \mathrm{mg} m \mathrm{CP} / 1$ & 86.9 & Decreased by 13.5 & {$[65]$} \\
\hline
\end{tabular}

${ }^{\mathrm{a}}$ The average sludge yield, $\mathrm{kg} \mathrm{SS} / \mathrm{kg} \mathrm{COD}{ }_{\text {removed }}$

COD consumption, and respiration of activated sludge [58]. About 50\% biomass reduction was achieved at a 2,4-dichlorophenol (DCP) concentration of $30 \mathrm{mg} / 1$ compared with no uncoupler. The strongest uncouplers were 2,4,5-trichlorophenol (TCP), $o$-nitro- $p$-chlorophenol, 2,4,6-tribromophenol, 2,6-dubromo-4-nitrophenol, and DCP. Strand et al. [59] compared effects of 12 chemical uncouplers on biomass yields in batch cultures for screening commercially available chemical uncouplers. The most effective of these uncouplers, 2,4,5trichlorophenol (TCP), was then tested in a bench scale, continuous flow and completely mixed activated sludge (CMAS) system treating simulated municipal wastewater, respectively. Initially, TCP addition reduced average yield by approximately $50 \%$, but sludge yield increased as TCP levels in the reactor decreased after 80 days. These results suggest that addition of chemical uncouplers to biological wastewater treatment systems can significantly reduce sludge production, but longterm bioacclimation can eventually negate the effects of uncoupler addition.

The effectiveness of para-nitrophenol ( $p \mathrm{NP})$ on reducing biomass production was investigated in a monoculture of Pseudomonas putida and an activated sludge system, respectively $[60,61]$. The biomass reduction increased up to $77 \%$ from $62 \%$ when the addition of $p \mathrm{NP}$ was $100 \mathrm{mg} / \mathrm{l}$ at $\mathrm{pH}$ of 6.2 and 7.0 , respectively. This showed that decrease in $\mathrm{pH}$ alone had no effect on biomass production, but caused additional biomass reduction induced by $p$ NP [60]. Though the same addition of $p \mathrm{NP}$ at $\mathrm{pH}$ of 7.7 as that in a monoculture of Pseudomonas putida was carried out in a lab scale activated sludge system, the biomass reduction was only $49 \%$ and the total substrate removal efficiency was also decreased by $25 \%$ [61]. Investigations of the biomass population indicated that a shift in the predominant species occurred upon the introduction of $p$ NP. And settling properties of activated sludge were adversely affected with a concomitant loss of protozoa and proliferation of filamentous bacteria at the addition of $p$ NP. The difference of biomass production in a monoculture and a mixed activated sludge may be caused by the biomass population shift, and subsequently lead to a metabolically less efficient and possibly $p$ NP tolerant biomass population.

After initial screening from 8 chemicals 2,4-dinitrophenol $(d \mathrm{NP})$ was selected and continuously dosed in a lab scale activated sludge system treating settled sewage [62]. The average sludge yield coefficient $(Y=0.30)$ at the addition of $35 \mathrm{mg} / 1 d \mathrm{NP}$ was significantly lower than that of the control $(Y=0.42)$, and the addition of $d \mathrm{NP}$ had little impact on BOD removal efficiency. It has been reported that $3,3^{\prime}, 4^{\prime}, 5$-tetrachlorosalicylanilide (TCS), a component in the formulations of soaps, rinses, and shampoos, etc., can stimulate the energy uncoupling in activated culture. Chen et al. $[63,64]$ evaluated the feasibility of using TCS as the energy uncoupler to reduce activated sludge production. The addition of 
TCS was effective in reducing the production of both batch and continuous activated sludge cultures. The TCS at $0.4 \mathrm{mg} / 1$ was found to be the threshold of triggering a sludge reduction, and the sludge production can be reduced by around $40 \%$ at the addition of 0.8 $1.0 \mathrm{mg} / \mathrm{l}$. With such TCS concentration, COD removal efficiency was not affected significantly [62,63]. Four chemical uncouplers ( $p \mathrm{CP}, m \mathrm{CP}, m \mathrm{NP}$ and $o \mathrm{NP}$ ) were compared for reducing sludge production in an activated sludge process. Results of batch experiments showed that $m \mathrm{CP}$ was the most effective for sludge reduction and had less effect on COD removal efficiency [65]. Liu [66] investigated the influence of the ratio of the initial chemical uncoupler ( $d \mathrm{NP}$ and $\mathrm{Zn}$ ) concentration $\left(C_{\mathrm{u}}\right)$ to the initial biomass concentration $\left(X_{0}\right)$ on the observed activated sludge yield. A model for quantitatively interpreting the relationship between the sludge yield and the chemical uncoupler was then developed for chemical uncoupler-containing batch culture of activated sludge, and verified with experimental and literature data. Experimental results clearly showed that the observed sludge yield decreased with increasing of the $C_{\mathrm{u}} / X_{0}$ ratio, which can better represent the real strength of the chemical uncoupler imposed to microorganisms than using $C_{\mathrm{u}}$ alone.

Chemical uncouplers may provide a promising way for sludge reduction because it only needs to add a set of chemical uncoupler dosing, but little is known about their uncoupling mechanisms and the connections between chemical uncouplers impact on sludge yield and process conditions. In these present experiments, chemical uncouplers were continuously dosed, and further work is needed to study changes of their dose way (intermittently adding) on sludge reduction. Chemical uncoupler application for sludge reduction may cause reduction of COD removal, increase oxygen consumption and worse activated sludge properties such as settling and dewatering. Interestingly, the impact of chemical uncouplers on nutrient removal seems neglected at present, and so does the connection of nutrient removal and chemical uncouplers. It should also be kept in mind that most of chemical uncouplers tested are xenobiotic and potentially harmful to the environment. Thus, their application should be very prudent and further research is needed for the environmental impact of chemical uncouplers application in long term.

\subsection{High $S_{O} / X_{O}$ ratio}

The most important parameter in batch cultivation of mixed cultures is the ratio of the initial substrate concentration to the initial biomass concentration ( $S_{0} / X_{0}$ as COD/biomass). There is strong evidence that the observed growth yield decreases significantly with the $S_{0} / X_{0}$ ratio increasing in the substrate-sufficient batch culture [67-70]. Such a phenomenon indicates that energy uncoupling between anabolism and catabolism occurs at high $S_{0} / X_{0}$ ratio. Two explanations are offered for this energy-uncoupling phenomenon induced by high $S_{0} / X_{0}$ ratio in the substrate-sufficient batch culture. The first mechanism was that energy dissipation by leakage of ions, such as protons or $\mathrm{K}^{+}$, through the cytoplasm membrane weakens the potential across it and thus subsequently uncouples oxidative phosphorylation. The second one is that the organisms induce a metabolic reaction pathway (the methylglyoxal bypass) that circumvents the energy conserving steps of glycolysis [1]. The high $S_{0} / X_{0}$ ratio ( $\geqslant 5 \mathrm{mg} \mathrm{COD} / \mathrm{mg}$ MLSS) may therefore act as an uncoupler of energy metabolism under substrate-sufficient conditions for reducing biomass production. For quantitatively explaining the role of the $S_{0} / X_{0}$ ratio in the biomass production and energy uncoupling for substrate-sufficient batch cultures of activated sludge, Liu [69] proposed a kinetic model to describe the effect of the $S_{0} / X_{0}$ ratio on the observed growth yield based on the balanced substrate reaction. A concept of energy uncoupling coefficient $\left(E_{\mathrm{u}}\right)$ was then postulated according to the observed biomass growth yield, from which a model was further developed to describe the relationship between $E_{\mathrm{u}}$ and the $S_{0} / X_{0}$ ratio [70]. The energy-uncoupling coefficient reaches 0.5 and 0.65 , respectively, when the $S_{0} / X_{0}$ ratio is greater than 5 and $10 \mathrm{mgCOD} / \mathrm{mg}$ MLSS, respectively. These indicate that a serious dissociation of catabolism from anabolism occurs at high $S_{0} / X_{0}$ ratio. These proposed models describe both experimental and literature data satisfactorily, and are capable of giving a theoretical basis for quantitatively interpreting the observed energy uncoupling in substrate-sufficient batch culture at various $S_{0} / X_{0}$ ratios. In domestic WWTPs the actual $S_{0} / X_{0}$ ratios are $0.01-0.13 \mathrm{mgCOD} / \mathrm{mg}$ MLSS depending on completely mixed or plug-flow systems [68]. Although the low sludge production can be achieved by engineering conditions of high $S_{0} / X_{0}$ ratio through increasing the food to microorganism ratio, further wastewater treatment would be necessary to reduce the concentration of organic pollutants in effluent to acceptable levels. It is no doubt that such strategy can cause the increasing capital and operation costs in biological wastewater treatment. Hence, this is especially applicable for the biological treatment of high strength industrial wastewater.

\subsection{Oxic-settling-anaerobic process}

A modified activated sludge system called oxicsettling-anaerobic (OSA) was investigated to reduce sludge production by an alternating exposure of activated sludge to oxic and anaerobic environments $[71,72]$. The OSA system consists of an oxic completely mixed tank, followed by a settling tank and an anaerobic tank, situated in the returned sludge circuit of the OSA 
system. A reduction in excess sludge production was observed in this OSA system. Comparison of this OSA process with a CAS process, the sludge yields were found in the ranges from 0.13 to $0.29 \mathrm{~kg} \mathrm{SS} / \mathrm{kg}$ $\mathrm{COD}_{\text {removed }}$ and from 0.28 to $0.47 \mathrm{~kg} \mathrm{SS} / \mathrm{kg} \mathrm{COD}$ removed, respectively. Different from their OSA system [71,72], a modified OSA process, a membrane module submerged in the aeration tank, was evaluated of its effect on sludge reduction [73]. When the oxidation-reduction potential (ORP) in the anaerobic tank was controlled at $-250 \mathrm{mV}$, the excess sludge can be reduced by $36 \%$ compared with that was controlled at $+100 \mathrm{mV}$ or $58 \%$ compared with CAS process. Their results showed that the OSA process could result in a significant decrease in excess sludge production, and the COD removal and sludge settleability could also be improved. This phenomenon of sludge reduction in the OSA system was explained by their proposed energy uncoupling theory [71,72]. This theory suggests that ATP content in the sludge depletes when sludge is retained in the anaerobic tank; when the sludge is returned to the aeration tank, ATP in the sludge would proliferate under the aerobic and foodsufficient conditions. Such a cyclic change in the ATP content in the sludge thus leads to an energy uncoupling between the catabolism and the anabolism, thereby inducing sludge reduction. Through extensively studying the mechanisms of sludge reduction in an OSA process, the effects of energy uncoupling, domination of slow growers, and soluble microbial products (SMPs) on sludge reduction could not be found [74,75]. The possible mechanism of sludge reduction in the OSA process is that sludge decay is accelerated effectively under a low ORP in the anaerobic tank. Such an increase in the sludge decay coefficient induced by a low ORP is able to explain a low production rate of the excess sludge in the OSA system [75]. However, the soluble COD increase in the anaerobic tank was observed in their experiments [73-75]. The cryptic growth in the aeration tank of the OSA process may be induced by the soluble COD increase of the returned sludge after its exposure in the anaerobic tank, and then cause low sludge production in the OSA system. In addition, the observed sludge yields in the anoxic reactor were $35-52 \%$ higher than in the aerobic reactor, and predation is thought to be responsible for differences in the observed sludge production between anoxic and aerobic conditions [49]. Therefore, further investigation on the carbon balance as well as microbial population examination is needed in order to understand the mechanism of sludge reduction in the OSA process.

\section{Maintenance metabolism}

Microorganisms satisfy their maintenance energy requirements in preference to producing additional biomass, and this recognition has revealed possible methods for sludge reduction during biological wastewater treatment. It is well known that increasing sludge retention time (SRT)/decreasing sludge loading rate can reduce sludge production in aerobic wastewater treatment processes [76]. Table 3 lists sludge reduction under long SRT and low $F / M$ ratio conditions. The energy available to microorganisms is determined by the supply of substrate. By increasing biomass concentration it would theoretically be possible to reach a situation in which the amount of energy provided equals the maintenance demand. A relationship was presented to describe substrate utilization for maintenance and biomass production in substrate-limited continuous microbial cultures [77]. Results showed that the biomass reduction occurred, i.e. biomass reduction by $12 \%$ and $44 \%$, respectively, when the biomass concentration was increased from 3 to $6 \mathrm{~g} / \mathrm{l}$ and from 1.7 to $10.3 \mathrm{~g} / \mathrm{l}$, respectively. It is impossible to increase the sludge concentration significantly in CAS processes by means of sedimentation, however.

\subsection{Membrane bioreactor}

MBR can be operated in long SRT even complete sludge retention because SRT can be controlled completely independently from hydraulic retention time (HRT) by membrane instead of clarifiers for the separation of sludge and effluent. The long/complete sludge retention allows MBR operation at much higher sludge concentration. The higher the sludge concentration, the lower the sludge loading rate. As a result, the microorganisms therefore utilize a growing portion of feed for maintenance purpose and consequently less for

Table 3

Literature data of maintenance metabolism for reducing excess sludge production

\begin{tabular}{llll}
\hline Operation conditions $\left(\mathrm{MBR}^{\mathrm{a}}\right)$ & $\begin{array}{l}\text { Sludge } \\
\text { reduction }(\%)\end{array}$ & $\begin{array}{l}\text { Sludge production } \\
(\mathrm{kg} / \mathrm{d})\end{array}$ & References \\
\hline Pilot side-stream MBR; pre-settled municipal wastewater & 100 & - & {$[80]$} \\
Pilot submerged MBR; municipal wastewater & 100 & - & $0.002-0.032$ \\
Pilot submerged MBR; $20^{\circ} \mathrm{C}$; pre-settled municipal wastewater & 100 & {$[82-84]$} \\
\hline
\end{tabular}

\footnotetext{
${ }^{\mathrm{a}}$ Complete sludge retention.
} 
growth. When the sludge loading rate becomes low enough, little or no excess sludge is produced any more.

Chaze and Huyard reported that sludge production of a bench scale side-stream MBR treating domestic wastewater was greatly reduced at long SRTs (50 and 100 days, respectively) [78]. The performance of a pilotscale side-stream MBR treating synthetic wastewater at SRTs ranging from 30 days to 2 days was extensively compared. Results showed that both sludge yield and biomass viability generally increased with decreasing SRT. Nitrification was little affected by the sludge age at higher SRTs, and the overall capacity of COD removal did not change significantly at different SRTs [79]. Little excess sludge in a pilot cross-flow MBR plant with complete sludge retention was produced when the sludge concentration increased to $40-50 \mathrm{~g} / 1$ resulting in only $6 \%$ of the carbon supplied was assimilated. However, complete sludge retention had little impact on wastewater treatment performance. The content of polluting trace elements were similar to that of a conventional treatment plant, though the fraction of inorganic compounds in sludge increased to $23.5 \%$ from $21.6 \%$ [80]. The low sludge production $(0.002-0.032 \mathrm{~kg} / \mathrm{d})$ was observed in a pilot submerged MBR operating for one year without sludge discharge (Table 3) [81]. Zero sludge production could be achieved at high sludge concentration $(15-23 \mathrm{~g} / \mathrm{l})$ and $F / M$ ratios as low as about $0.07 \mathrm{KgCOD}(\mathrm{kg} \mathrm{MLSS})^{-1} \mathrm{~d}^{-1}$ in a pilot submerged MBR with complete sludge retention [82,83]. Their investigations showed that the sludge reduction in MBR systems by higher organisms (protozoa/metazoa) was ruled out, and bacteria maintenance metabolism caused little/zero sludge production [80-85]. The absence of protozoa and metazoa in MBR systems occurred in their observations, but no reason was given to explain it.

MBR process has obvious advantages over CAS processes, e.g. excellent effluent quality, small footprint, less sludge production and flexibility of operation, and becomes a promising alternative for wastewater treatment [86]. However, the sludge properties of MBR, i.e. small, weak and open sludge flocs, high viscosity and high SVI, make sludge settling and dewatering more difficult. Problems commonly encountered under high SRT operation of MBR are poor oxygenation leading to increased aeration cost, and extensive membrane fouling which requires frequent membrane cleaning and replacement. It is therefore not feasible to operate MBR with complete sludge retention in practice, and there must exist a minimal rate at which excess sludge is wasted in order to keep an optimal range of sludge concentration in MBR. This amount of sludge discharged should be much less than the amount of excess sludge produced in CAS processes. At present, the sludge concentrations in MBR typically vary from 15 to $20 \mathrm{~g} / 1$ [83]. Although MBR has successfully been applied in full-scale WWTPs, a cost analysis shows that the costs of sludge treatment and disposal will be the main factor of total plant operation costs since 2004 instead of the costs of membrane module replacement [87].

\section{Predation on bacteria}

A biological wastewater treatment process can be considered as an artificial ecosystem, and activated sludge is an ideal habitat for several organisms other than bacteria. One way to reduce sludge production is to exploit higher organisms such as protozoa and metazoa in the activated sludge processes that predate on the bacteria whilst decomposition of substrate remains unaffected. During energy transfer from low to high trophic levels, energy is lost due to inefficient biomass conversion. Under optimal conditions the total loss of energy will be maximal and the total biomass production will thus be minimal [6]. In an activated sludge system the grazing fauna mainly consists of protozoa and occasionally metazoa. Protozoa present $<1 \%$ of the total dry-weight of a wastewater biomass, and $70 \%$ of protozoa are ciliates $[6,88]$. The protozoa can be divided into four groups: ciliates (free swimming, crawling and sessile), flagellates, amoeba, and heliozoa [89]. The metazoa consist normally of rotifera and nematoda. Other metazoa, such as Aeolosomatidae and Naididae, occur at a low number or occasionally as a bloom. Trickling filters usually contain the same organisms as can be found in activated sludge system but with larger metazoa populations.

It is well known that the presence of protozoa and metazoa in aerobic wastewater treatment processes plays an important role in keeping the effluent clear by consuming dispersed bacteria. In the past, protozoa and metazoa were usually used as important indicators of process performance and efficiency in biological wastewater treatment processes. Recently, many researchers have focused on sludge reduction induced by grazing on bacteria [90-107]. Table 4 summarizes sludge reduction induced by grazers.

\subsection{Two-stage system}

In conventional aerobic wastewater treatment processes, the presence of predators suppresses the growth of dispersed bacteria and favours the growth of floc or film forming bacteria, which are more protected against predation. For overcoming this selection pressure, a two-stage system was developed for sludge reduction $[90,95]$. The first stage (the bacterial stage) is operated as a chemostat without biomass retention and at a short SRT to induce dispersed bacterial growth. The second stage is designed as a predator stage (activated sludge or biofilm processes) with a long SRT for growth of protozoa and metazoa. The HRT $(=\mathrm{SRT})$ is the critical 
Table 4

Literature data of predation on bacteria for reducing excess sludge production

\begin{tabular}{|c|c|c|c|}
\hline Operation conditions & $\begin{array}{l}\text { Sludge yield } \\
(\mathrm{kg} \mathrm{SS} / \mathrm{kg} \mathrm{COD} \\
\text { removed })\end{array}$ & $\begin{array}{l}\text { Sludge } \\
\text { reduction }(\%)\end{array}$ & References \\
\hline \multicolumn{4}{|l|}{ Two-stage system } \\
\hline $\begin{array}{l}\text { Lab scale; } 30^{\circ} \mathrm{C} ; \mathrm{pH}=7 \text {; bacteria }(P \text {. fluorescens); ciliate } \\
(T \text {. pyriformis })\end{array}$ & - & $12-43$ & {$[90]$} \\
\hline Lab scale; $30^{\circ} \mathrm{C} ; \mathrm{pH}=7$; synthetic wastewater & $0.05-0.17$ & - & {$[91,92]$} \\
\hline Lab scale; $30^{\circ} \mathrm{C} ; \mathrm{pH}=7$; pulp and paper wastewater & $0.01-0.23$ & - & {$[93]$} \\
\hline $\begin{array}{l}\text { Lab scale; the first stage }\left(20-27^{\circ} \mathrm{C} ; \mathrm{pH}=7.8-8.5\right) \text {, the second stage } \\
\left(18-30^{\circ} \mathrm{C} ; \mathrm{pH}=7.6-8.3\right) \text {; synthetic wastewater }\end{array}$ & - & $20-30$ & {$[94,95]$} \\
\hline \multicolumn{4}{|l|}{ Oligochaetes } \\
\hline \multirow[t]{2}{*}{$\begin{array}{l}\text { Two pilot tricking filters (filled with lava slags and plastic media, } \\
\text { respectively); } 18-23^{\circ} \mathrm{C} \text {; excess sludge }\end{array}$} & - & $\begin{array}{l}10-50 \text { (lava } \\
\text { slags) }\end{array}$ & \\
\hline & & $\begin{array}{l}10-45 \text { (plastic } \\
\text { media) }\end{array}$ & {$[98,102,103]$} \\
\hline Pilot activated sludge system; $18-23^{\circ} \mathrm{C}$; domestic wastewater & 0.15 & - & {$[98,102,103]$} \\
\hline Pilot oxidation ditch; $18-23^{\circ} \mathrm{C}$; domestic wastewater & 0.17 & - & {$[98,102,103]$} \\
\hline Pilot suction submerged $\mathrm{MBR} ; 20^{\circ} \mathrm{C}$; municipal wastewater & $0.00-0.12$ & - & {$[104,105]$} \\
\hline Pilot gravitational submerged $\mathrm{MBR} ; 20^{\circ} \mathrm{C}$; municipal wastewater & $0.10-0.15$ & - & {$[104,105]$} \\
\hline Pilot activated sludge system; $20^{\circ} \mathrm{C}$; domestic wastewater & 0.17 & - & {$[106]$} \\
\hline
\end{tabular}

design parameter for the first stage. It must be long enough to avoid washout of dispersed bacteria and short enough to prevent the growth of higher organisms grazing on the bacteria.

Ratsak et al. [90] studied the biomass reduction induced by the ciliate $T$. pyriformis grazing on $P$. fluorescens in a two-stage pure culture chemostatsystem, and $12-43 \%$ of biomass reduction was observed. The minimization of sludge production by protozoa and metazoa predation on bacteria was investigated in two two-stage systems treating two synthetic wastewaters, in which the second stage was a suspended-carrier biofilm reactor $[91,92]$. The sludge production in the predator stage was significantly decreased by $60-80 \%$ compared with that in the bacterial stage. The total sludge yields were $0.05 \mathrm{~g} \mathrm{TSS} / \mathrm{g} \mathrm{COD}_{\text {removed }}$ in a two-stage system fed acetic acid, whereas it was $0.17 \mathrm{~g} \mathrm{TSS} / \mathrm{g} \mathrm{COD}_{\text {removed }}$ in another two-stage system fed methanol. Further study was carried out to investigate the sludge reduction with this two-stage system treating different pulp and paper industry wastewater (the second stage designed as activated sludge and biofilm reactors, respectively) [93]. Results of this study showed that the sludge yields (0.01-0.23 g TSS $\left./ \mathrm{g} \mathrm{COD}_{\text {removed }}\right)$ of this two-stage system were obviously lower than those $(0.2-0.4 \mathrm{~g} \mathrm{TSS} / \mathrm{g}$ $\mathrm{COD}_{\text {removed }}$ ) in CAS processes treating the same wastewater. It was also observed in their experiments that the dominant microfauna in the second stage was filterfeeding protozoa and metazoa, and the effect of larger metazoa, such as oligochaetes, on sludge reduction seemed to be insignificant [92,93]. Ghyoot and coworkers $[94,95]$ compared the performance of different two-stage systems treating synthetic wastewater (the second stage designed as a CAS reactor and a submerged MBR). The sludge yield of the two-stage submerged MBR system was 20-30\% lower than that of the two-stage CAS system under similar SRT and $F / M$ ratio. This phenomenon was attributed to more predators' presence in the submerged MBR than those in the CAS reactor. However, the increased grazing of predators in the two-stage MBR system not only decreased the capacity of nitrification, but also resulted in $\mathrm{N}$ and $\mathrm{P}$ concentration increase in the effluent.

Generally, population growth of protozoa and metazoa is mainly limited by the amount of food available, and the physical properties (size of the mouth and pharynx) of protozoa and metazoa have impact on their grazing of sludge flocs. For example, one of problems in encouraging bdelloid rotifer growth may be the availability of sludge flocs in the size range $(0.2-3 \mu \mathrm{m})$ ingestible by rotifers [96] because the size of most of sludge flocs is bigger than that. This might be overcome by partial sludge disintegration prior to the grazing stage of protozoa and metazoa. In terms of sludge reduction, two-stage systems (the second stage designed as either the biofilm process with stationary support material or the MBR) were more efficient than those two-stage CAS systems. For a two-stage process, HRT $(=$ SRT) in the first stage is very long so that it will greatly increase not only the working volume of bioreactor, but also its capital and operation costs. It is generally not feasible to apply the two-stage process in practice. 


\subsection{Oligochaetes}

Worms are the largest organisms observed during the microscopic investigation of activated sludge [89], and may have more potential on sludge reduction in practical application than protozoa due to their bigger sizes. The performance of oligochaetes on sludge reduction in biological wastewater treatment is paid more attention recently. The main types of worms present in activated sludge system and trickling filters are Naididae, Aeolosomatidae and Tubificidae. Naididae and Aeolosomatidae are free-swimming worms. Tubificidae are sessile worms that do not normally occur in activated sludge suspensions, but are sometimes present in sludge 'bankets' on the basin bottom. Under normal conditions, Naididae and Aeolosomatidae propagate by division into an anterior and a somewhat smaller posterior part. The reproduction of Tubificidae takes place sexually in most cases. Tubificidae prefer darkness [97,98]. According to Learner's investigation [99], naidid worms occurrence and abundance in filter beds were determined principally by the organic loading, the amount of film present, and the presence of industrial waste. Oligochaete worms predominate in light to moderately loaded filter beds (up to $0.2 \mathrm{~kg} \mathrm{BOD} /$ $\mathrm{m}^{3} \mathrm{~d}$ ) and are unlikely to play a significant role in more heavily loaded filter beds. Activated sludge containing many worms usually originates from sewage treatment plants with a sludge load of $0.1 \mathrm{~kg} \mathrm{BOD} / \mathrm{kg}$ MLSS d [89].

The behaviour of oligochaete worms in a full-scale activated sludge plant was studied during 1.5 years [100,101]. Different worms were found, Nais elinguis, Pristina sp. and Aeolosoma hemprichicii, but Nais elinguis was predominant. The number of worms varied both seasonally and among the aeration tanks. A major worm bloom resulted in a low sludge volume index, lower energy consumption for oxygen supply and less sludge disposal $(25-50 \%$ sludge reduction). Due to uncontrollability of Aeolosomatidae and Naididae i.e. their washout in effluent, Tubificidae was selected and its performances on sludge reduction were compared in different aerobic wastewater treatment processes equipped with carriers [98,102,103]. Trickling filters filled with lava slags and plastic media, respectively, were continuously fed with a certain quantity of excess sludge from a sewage treatment plant by recirculation. Sludge reductions of $10-50 \%$ and $10-45 \%$ in the trickling filters with lava slags and plastic media, respectively, were achieved with worms compared with $10-15 \%$ and $10 \%$ without worms, respectively. The sludge yield in a pilot activated sludge system equipped with plastic carrier for treating pre-settled domestic wastewater was decreased from $0.40 \mathrm{~g}$ MLSS/ $\mathrm{gCOD}_{\text {removed }}$ without Tubificidae to $0.15 \mathrm{gMLSS} / \mathrm{g}$ $\mathrm{COD}_{\text {removed }}$ with Tubificidae. The sludge yield in the oxidation ditch (carriers placed in the ditch) fed with unsettled domestic wastewater was $0.17 \mathrm{gMLSS} / \mathrm{g}$ $\mathrm{COD}_{\text {removed }}$ with worms compared with $0.22 \mathrm{~g} \mathrm{MLSS/}$ $\mathrm{gCOD}_{\text {removed }}$ without worms. No attachment of worms occurred on the carrier of a biorotor fed with the same sludge as the tricking filters, though worms still remained in the suspension. Besides temperature, their results showed that the presence of a physical niche was an essential abiotic factor for the growth and retention of worms in biological wastewater treatment systems.

Different from their way of using carriers [98,102,103], Zhang [104] and Eikelboom et al. [105] studied the possibility of increasing worm density with membrane, and compared performances of worms on sludge reduction in different pilot MBRs fed with presettled domestic wastewater. Their results showed that Nais elinguis, Pristina sp. and Aeolosoma hemprichicii were found, but Aeolosoma was predominant, contrary to the finding of Ratsak not MBR but CAS [100,101]. High worm density i.e. 2600-3800 Aeolosoma/ml mixed liquor once occurred in the membrane separation tank of a two-stage gravitational submerged MBR system, and resulted in a low sludge yield $(0.10$ $0.15 \mathrm{~kg} \mathrm{SS} / \mathrm{kg} \mathrm{COD}$ removed$)$. The sludge yield in a suction submerged MBR system varied from 0.00 to $0.12 \mathrm{~kg} \mathrm{SS} /$ $\mathrm{kgCOD}$ removed at more than 100 Aeolosoma per $\mathrm{ml}$ of mixed liquor. A same phenomenon occurred in all of their experiments that worm bloom and disappearance alternatively appeared, but little was known about it. In order to further explore stable worm growth and investigate membrane impacts on worm growth in the long term, sludge reduction induced by oligochaetes were compared in a two-stage submerged MBR and a CAS reactor [106]. In this study, worm growth in the CAS reactor was much better than in the MBR. The average worm density of the aeration tank in the CAS reactor was 71 total worms/mg VSS, much higher than that in the MBR (10 total worms/mg VSS). Worms in the CAS reactor occurred nearly throughout the operating period and continuously maintained at over 30 total worms/mg VSS in the aeration tank for 172 days. Worms did not naturally produce in the MBR, and the dominant worm type in the MBR depended on sludge inoculation from the CAS reactor. Different from their observations [100,101,104,105], the alternating dominance of worm types in both reactors changed between Aeolosoma and Nais. And the time of Aeolosoma dominance was longer than that of Nais dominance. So big difference of worm growth in MBR and the CAS reactor may be mainly caused by the difference of microbial community in both reactors. Worm growth in the MBR contributed to neither sludge reduction nor improvement of sludge settling due to low density. But worm presence and bloom in the CAS reactor greatly decreased sludge yield and improved sludge settling at high density. Both the average sludge yield $(0.17 \mathrm{~kg} \mathrm{SS} /$ $\mathrm{kgCOD}$ removed $)$ and SVI $(60 \mathrm{ml} / \mathrm{g})$ in the CAS reactor 
were much lower than in the MBR $(0.40 \mathrm{kgSS} / \mathrm{kg}$ $\mathrm{COD}_{\text {removed }}$ and $133 \mathrm{ml} / \mathrm{g}$ ). The impacts of eight operation parameters (TSS, HRT, SRT, $F / M$, recycle ratio, temperature, $\mathrm{pH}$, and DO) on worm growth in both reactors were also investigated. Only sludge loading rate $(F / M)$ had no impact on worm growth in the MBR, and SRT was the only parameter that did not affect worm growth in the CAS reactor [106]. In contrast with observations reported by Lee and Welander [107] and by Ghyoot verstraete [95], the nitrification process was not disturbed by worm growth [98,102-106]. It is no doubt that worm bloom can cause release of phosphate into effluent, but such impact of worm growth on $\mathrm{PO}_{4}^{3-}-\mathrm{P}$ increase in effluent was not heavy. Contrary to all of our results, Luxmy et al. [108] reported that the presence (even about 1000-2000 metazoa population per ml) or absence of the metazoa population did not have any significant effect on sludge reduction in bench scale of submerged MBRs. However, metazoa population may play an effective role in membrane fouling control, especially those that were attached to the membrane.

Although the presence of worms may lead to a substantial sludge reduction, the practical application is still uncontrollable because the connection between operation parameters and worm growth is missing. Another challenge of sludge reduction induced by Oligochaeta is how to control and maintain their stable growth at high density for long time, especially in the full-scale application. For sludge reduction induced by predation on bacteria, further research should also be needed on the relationship between food chain (preypredator) and the sludge flocs formation-disintegration.

\section{Discussion}

The strategies for sludge reduction should be evaluated and chosen for practical application using costs analysis and assessment of environmental impact. The cost analysis includes the additional capital and operating costs caused by strategies, and benefits brought by reduced sludge treatment and disposal. The environmental impact induced by strategies of minimization excess sludge production should be assessed, i.e. odor problems, nutrients release, and toxicity of trace chemical uncoupler in effluent. The drawbacks of each strategy for sludge reduction should be considered and assessed when the benefits of minimization sludge production are seeking. Table 5 summarizes advantages and disadvantages of different strategies for sludge reduction. At present both sludge ozonation and MBR has been successfully applied in practice, but other methods based on uncoupling metabolism and predation on bacteria are still in the stage of lab scale or pilot scale experiments. Due to high costs caused from ozone production e.g. over $50 \%$ of the total operation costs
[32], it is important to decrease the amounts of ozone required for sludge reduction. The amounts of ozone required for eliminating excess sludge production are determined by the gas phase ozone concentration, the ozonation way (continuous or intermittent ozone dose), ozone reactor configuration (bubble or airlift reactor), and the concentration of sludge treated by ozone. The OSA process may present a potential cost-effective solution to the excess sludge problem in an activated sludge process because addition of an anaerobic tank is only needed. The main disadvantages of the OSA system were even higher sludge production caused sometimes by an ORP disturbance and costs raised by the addition of an anaerobic tank. In order to further decrease MBR capital and operating costs more research should focus on membrane materials, design of membrane module, the impact of membrane on microbial community, membrane fouling and its countermeasures. Sludge reduction induced by oligochaetes would provide a promising and environmental friendly way for WWTPS if the problem of unstable worm growth is solved.

In general, nutrients such as nitrogen and phosphorus are required to treat $\mathrm{BOD}$ in biological wastewater treatment processes. Parts of nutrients are incorporated into the biomass, and then withdrawn with excess sludge. From the point view of sludge mineralization an increase of phosphorus, nitrogen (nitrate), $\mathrm{CO}_{2}$ and even dissolved COD hardly seems avoidable. The nutrient concentrations in effluent would be expected to be equal to or more than those in influent for sludge reduction. Hence, it should be paid more attention to such strategies as lysis-cryptic growth and predation on bacteria, because nutrients release into effluent increases downstream nutrient removal requirements and results in eutrophication and deoxygenation in the receiving waters. These strategies for sludge reduction may increase the total oxygen demand and thus result in an increase in the aeration costs. Employing any strategy for sludge reduction has an impact on microbial community (e.g. microbial population shift) that may influence the sludge settling and dewatering, and the effluent quality. Application of novel analytical and investigative methods such as modern molecular biological techniques can lead to new insights into the impact on microbial community.

\section{Conclusion}

Excess sludge treatment and disposal represents a rising challenge for wastewater treatment plants due to economic, environmental and regulation factors. There is therefore considerable interest in developing technologies for reducing sludge production in biological wastewater treatment processes. A considerable scope for reducing sludge production exists according to 
Table 5

Comparison of different strategies for reducing excess sludge production

\begin{tabular}{llll}
\hline Strategy & $\begin{array}{l}\text { Estimated total costs } \\
\left(\mathrm{US} \$ \mathrm{~m}^{3} \text { wastewater }\right)^{\mathrm{a}}\end{array}$ & Advantages & $\begin{array}{l}\text { Disadvantages and } \\
\text { environmental impact }\end{array}$ \\
\hline $\begin{array}{l}\text { Lysis-cryptic growth } \\
\text { Ozonation [32] }\end{array}$ & 0.11 (operation costs) $)^{\mathrm{b}}$ & Successful full scale experience & $\begin{array}{l}\text { High costs involved in } \\
\text { ozonation; the waste ozone } \\
\text { Decrease of COD removal rate, } \\
\text { bad sludge settling } \\
\text { characteristics; formation of } \\
\text { ThM }\end{array}$ \\
& - & Cheaper than ozonation & $\begin{array}{l}\text { Thorrosion, subsequent } \\
\text { neutralisation; odor }\end{array}$ \\
$\begin{array}{l}\text { Thermal or thermo-chemical } \\
\text { treatment }\end{array}$ & - & Relatively simple & Energy intensive \\
MBR-ultrasound system & - & High efficiency of lysis & High aeration cost
\end{tabular}

Maintenance metabolism

MBR [109] $8.72-5.48^{\mathrm{c}}$

Uncoupling metabolism

Chemical uncoupler

High $S_{0} / X_{0}$

OSA

Predation on bacteria

Two-stage system

Oligochaete
-

-

一

-
Flexible operation, high effluent quality, small footprint

Relatively simple

No addition of materials and energy

Only addition of an anaerobic tank

Stable operation

Relatively simple
High costs, membrane fouling

\footnotetext{
${ }^{\mathrm{a}}$ Total costs $=$ total capital costs + total operation and maintenance costs.

${ }^{\mathrm{b}} 1 \mathrm{US} \$=120 \mathrm{JP} ¥$; the capacity of wastewater treatment deduced from Yasui et al. [32] $=5000 \mathrm{~m}^{3} / \mathrm{d}$.

${ }^{\mathrm{c}}$ Submerged MBR at HRT $=4 \mathrm{~h}, \mathrm{SRT}=15$ days and MLSS $=10 \mathrm{~g} / 1$ with the capacity of 3785 and $18,927 \mathrm{~m}^{3} / \mathrm{d}$, respectively.
}

strategies based on mechanisms of lysis-cryptic growth, uncoupling metabolism, maintenance metabolism, and bacteriovorous predation. Benefits can be realized from these different strategies, but capital, operational and environment costs incurred by them must be considered. Important bottlenecks still have to be overcome i.e. costs reduction for spreading ozonation-cryptic growth and MBR in practice. Major problems of several strategies should be solved for their practical application such as bioacclimation of chemical uncoupler and stable worm growth.

\section{Acknowledgements}

This work was financially supported by the cooperative project "Development of membrane bioreactor for treatment and reuse of urban wastewater (II): zero sludge production" between TNO Environment, Energy and Process Innovation and Research Center for EcoEnvironment Sciences, Chinese Academy of Sciences.

\section{References}

[1] Low EW, Chase HA. Reducing production of excess biomass during wastewater treatment. Water Res 1999;33(5):1119-32.

[2] Gray NF. Biology of wastewater treatment. UK: Oxford University Press; 1989.

[3] Metcalf, Eddy. Wastewater engineering: treatment, disposal and reuse, 3rd ed. New York: McGraw-Hill; 1991. p. 529-91.

[4] Davis RD, Hall JE. Production, treatment and disposal of wastewater sludge in Europe from a UK perspective. Eur Water Pollut Control 1997;7(2):9-17.

[5] Spellman FR. Wastewater biosolids to compost. Lancaster, PA, USA: Technomic Publishing Company: 1997. p. $223-35$. 
[6] Ratsak CH, Maarsen KA, Kooijman SAL. Effects of protozoa on carbon mineralization in activated sludge. Water Res 1996;30(1):1-12.

[7] Mayhew M, Stephenson T. Low biomass yield activated sludge: a review. Environ Technol 1997;18:883-92.

[8] Liu Y, Tay JH. Strategy for minimization of excess sludge production from the activated sludge process. Biotechnol Adv 2001;19(2):97-107.

[9] Mason CA, Hamer G, Bryers JD. The death and lysis of microorganism in environmental process. FEMS Microbiol Rev 1986;39:373-401.

[10] Kepp U, Machenbach I, Weisz N, Solheim OE. Enhanced stabilisation of sewage sludge through thermal hydrolysis - three years of experience with a full scale plant. Water Sci Technol 1999;42(9):89-96.

[11] Barjenbruch M, Hoffmann H, Tränker J. Minimizing of foaming in digesters by pre-treatment of the surplussludge. Water Sci Technol 1999;42(9):235-42.

[12] Tanaka S, Kobayashi T, Kamiyama K, Bildan ML. Effects of thermochemical pre-treatment on the anaerobic digestion of waste activated sludge. Water Sci Technol 1997;36(8):209-15.

[13] Baier U, Schmidheiny P. Enhanced anaerobic degradation of mechanically disintegrated sludge. Water Sci Technol 1997;36(11):137-43.

[14] Kopp J, Müller J, Dichtl N, Schwedes J. Anaerobic digestion and dewatering characteristics of mechanically disintegrated excess sludge. Water Sci Technol 1997;36(11):129-36.

[15] Camacho P, Geaugey V, Ginestet P, Paul E. Feasibility study of mechanically disintegrated sludge and recycle in the activated-sludge process. Water Sci Technol 2002; 46(10):97-104.

[16] Nolasco MA, Campos ALO, Springer AM, Pires EC. Use of lysis and recycle to control excess sludge production in activated sludge treatment: bench scale study and effect of chlorinated organic compounds. Water Sci Technol 2002;46(10):55-61.

[17] Tiehm A, Nickel K, Neis U. The use of ultrasound to accelerate the anaerobic digestion of sewage sludge. Water Sci Technol 1997;36(11):121-8.

[18] Tiehm A, Nickel K, Zellhorn, Neis U. Ultrasonic waste activated sludge disintegration for improving anaerobic stabilization. Water Res 2001;35(8):2003-9.

[19] Chu CP, Chang BV, Liao GS, Jean DS, Lee DJ. Observation on changes in ultrasonically treated waste-activated sludge. Water Res 2001;35(4): 1038-46.

[20] Onyeche TI, Schläfer O, Bormann H, Schröder C, Sievers M. Ultrasonic cell disruption of stablised sludge with subsequent anaerobic digestion. Ultrasonics 2002; 40(1-8):31-5.

[21] Chu CP, Feng WC, Chang BV, Chou CH, Lee DJ. Reduction of microbial density level in wastewater activated sludge via freezing and thawing. Water Res 1999;33(16):3532-5.

[22] Guellil A, Boualam M, Quiquampoix H, Ginestet P, Audic JM, Block JC. Hydrolysis of wastewater colloidal organic matter by extra-cellular enzymes extracted from activated sludge flocs. Water Sci Technol 2001;43(6):33-40.
[23] Weemaes M, Grootaerd H, Simoens F, Huysmans A, Verstraete W. Ozonation of sewage sludge prior to anaerobic digestion. Water Sci Technol 2000;42(9):175-8.

[24] Weemaes M, Grootaerd H, Simoens F, Verstraete W. Anaerobic digestion of ozonized biosolids. Water Res 2000;34(8):2330-6.

[25] Neyens E, Baeyens J, Weemaes M, De heyder B. Pilotscale peroxidation $\left(\mathrm{H}_{2} \mathrm{O}_{2}\right)$ of sewage sludge. J Hazard Mater 2003;98(1-3):91-106.

[26] Shanableh A. Production of useful organic matter from sludge using hydrothermal treatment. Water Res 2000;34(3):945-51.

[27] Saiki Y, Imabayashi S, Iwabuchi C, Kitagawa Y, Okumura Y, Kawamura H. Solubilization of excess activated sludge by self-digestion. Water Res 1999; 33(8):1864-70.

[28] Neyens E, Baeyens J, Weemaes M, De heyder B. Hot acid hydrolysis as a potential treatment of thickened sewage sludge. J Hazard Mater 2003;98(1-3):275-93.

[29] Neyens E, Baeyens J, Weemaes M, De heyder B. Alkaline thermal sludge hydrolysis. J Hazard Mater 2003; 97(1-3):295-314.

[30] Chiu YC, Chang CN, Lin JG, Huang SJ. Alkaline and ultrasonic pretreatment of sludge before anaerobic digestion. Water Sci Technol 1997;36(11):155-62.

[31] Yasui H, Shibata M. An innovative approach to reduce excess sludge production in the activated sludge process. Water Sci Technol 1994;30(9):11-20.

[32] Yasui H, Nakamura K, Sakuma S, Iwasaki M, Sakai Y. A full-scale operation of a novel activated sludge process without excess sludge production. Water Sci Technol 1996;34(3-4):395-404.

[33] Sakai Y, Fukase T, Yasui H, Shibata M. An activated sludge process without excess sludge production. Water Sci Technol 1997;36(11):163-70.

[34] Kamiya T, Hirotsuji J. New combined system of biological process and intermittent ozonation for advanced wastewater treatment. Water Sci Technol 1998;38(8-9):145-53.

[35] Egemen E, Corpening J, Padilla J, Brennan R, Nirmalakhandan $\mathrm{N}$. Evaluation of ozonation and cryptic growth for biosolids management in wastewater treatment. Water Sci Technol 1999;39(10-11):155-8.

[36] Egemen E, Corpening J, Nirmalakhandan N. Evaluation of an ozonation system for reduced waste sludge generation. Water Sci Technol 2001;44(2-3):445-52.

[37] Deleris S, Geaugey V, Camacho P, Debellefontaine H, Paul E. Minimization of sludge production in biological processes: an alternative solution for the problem of sludge disposal. Water Sci Technol 2002;46(10):63-70.

[38] Ahn KH, Park KY, Maeng SK, Hwang JH, Lee JW, Song KG, Choi S. Ozonation of wastewater sludge for reduction and recycling. Water Sci Technol 2002; 46(10):71-7.

[39] Chen GH, Saby S, Djafer M, Mo HK. New approaches to minimize excess sludge in activated sludge systems. Water Sci Technol 2001;44(10):203-8.

[40] Saby S, Djafer M, Chen GH. Feasibility of using a chlorination step to reduce excess sludge in activated sludge process. Water Res 2002;36(3):656-66. 
[41] Canales A, Pareilleux A, Rols J, Goma G, Huyard A. Decreased sludge production strategy for domestic wastewater treatment. Water Sci Technol 1994;30(8):97-106.

[42] Yoon SH, Kim HS. The use of MBR-ultrasound system for zero excess sludge production. Process Biochem, 2003, submitted for publication.

[43] Pasveer A. Een vorm van slibvernietiging. Het oxylyseproces. $\mathrm{H}_{2} \mathrm{O}$ 2001;4(25):580-8.

[44] Rocher M, Goma G, Begue AP, Louvel L, Rols JL. Towards a reduction in excess sludge production in activated sludge processes: biomass physicochemical treatment and biodegradation. Appl Microbiol Biotechnol 1999;51(6):883-90.

[45] Rocher M, Roux G, Goma G, Begue AP, Louvel L, Rols JL. Excess sludge reduction in activated sludge processes by integrating biomass alkaline heat treatment. Water Sci Technol 2001;44(2-3):437-44.

[46] Abbassi B, Dullstein S, Rabiger N. Minimization of excess sludge production by increase of oxygen concentration in activated sludge flocs: experimental and theoretical approach. Water Res 2000;34(1):139-46.

[47] Dignac MF, Derenne S, Ginestet P, Bruchet S, Knicker $\mathrm{H}$, Largeau C. Determination of structure and origin of refractory organic matter in bio-epurated wastewater via spectroscopic methods. Comparison of conventional and ozonation treatments. Envion Sci Technol 2000; 34(16):3389-94.

[48] Tian S, Lishman L, Murphy KL. Investigation into excess sludge activated sludge accumulation at low temperatures. Water Res 1994;28(3):501-9.

[49] Lishman LA, Murphy KL. The significance of hydrolysis in microbial death and decay. Water Res 1994;28:2417-9.

[50] Lishman LA, Legge RL, Farquhar GJ. Temperature effects on wastewater treatment under aerobic and anoxic conditions. Water Res 2000;36(8):2263-76.

[51] Müller JA. Prospects and problems of sludge pretreatment processes. Water Sci Technol 2001;44(10): 121-8.

[52] Yoon SH. Important operational parameters of membrane bioreactor-sludge disintegration system for zero excess sludge production. Water Res 2003;37(8):1921-31.

[53] Neyens E, Baeyens J. A review of thermal sludge pretreatment processes to improve dewaterability. J Hazard Mater 2003;98(1-3):51-67.

[54] Weemaes MPJ, Verstraete W. Evaluation of current wet sludge disintegration techniques. J Chem Technol Biotechnol 1998;73:83-92.

[55] Senez JC. Some considerations on the energetics of bacterial growth. Bacteriol Rev 1962;26:95-107.

[56] Stouthamer AH. Correlation of growth yields. In: Quayle JR, editor. Microbial biochemistry, international review of biochemistry, vol. 21. Baltimore: University Park; 1979. p. 1-47.

[57] Russel JB, Cook GM. Energetics of bacterial growth: balance of anabolic and catabolic reactions. Microbiol Rev 1995;59(1):48-62.

[58] Okey RW, Stensel HD. Uncouplers and activated sludge - the impact on synthesis and respiration. Toxical Environ Chem 1993;40:235-54.
[59] Strand SE, Harem GN, Stensel HD. Activated-sludge yield reduction using chemical uncouplers. Water Environ Res 1999;71(4):454-8.

[60] Low EW, Chase HA. The use of chemical uncouplers for reducing biomass production during biodegradation. Water Sci Technol 1998;37(4-5):399-402.

[61] Low EW, Chase HA, Milner MG, Curtis TP. Uncoupling of metabolism to reduce biomass production in the activated sludge process. Water Res 2000;34(12):3204-12.

[62] Mayhew M, Stephenson T. Biomass yield reduction: is biochemical manipulation possible without affecting activated sludge process efficiency? Water Sci Technol 1998;38(8-9):137-44.

[63] Chen GH, Mo HK, Saby S, Yip WK, Liu Y. Minimization of activated sludge production by chemically stimulated energy spilling. Water Sci Technol 2000; 42(12):189-200.

[64] Chen GH, Mo HK, Liu Y. Utilization of a metabolic uncoupler, 3,3', $4^{\prime}, 5$-tetrachlorosalicylanilide (TCS) to reduce sludge growth in activated sludge culture. Water Res 2002;36(8):2077-83.

[65] Yang XF, Xie ML, Liu Y. Metabolic uncouplers reduce excess sludge production in an activated sludge process. Process Biochem 2003;38(9):1373-7.

[66] Liu Y. Effect of chemical uncoupler on the observed growth yield in batch culture of activated sludge. Water Res 2000;34(7):2025-30.

[67] Chudoba P, Chevalier JJ, Chang J, Capdeville B. Effect of anaerobic stabilization of activated sludge on its production under batch conditions at various $S_{0} / X_{0}$ ratios. Water Sci Technol 1991;23:917-26.

[68] Chudoba P, Capdeville B, Chudoba J. Explanation of biological meaning of the $S_{0} / X_{0}$ ratio in batch cultivation. Water Sci Technol 1992;26(3-4):743-51.

[69] Liu Y. Bioenergetic interpretation on the $S_{0} / X_{0}$ in substrate-sufficient batch culture. Water Res 1996; 30(11):2766-70.

[70] Liu Y, Chen GH, Paul E. Effect of the $S_{0} / X_{0}$ ratio on energy uncoupling in substrate-sufficient batch culture of activated sludge. Water Res 1998;32(10):2833-88.

[71] Chudoba P, Chudoba J, Capdeville B. The aspect of energetic uncoupling of microbial growth in the activated sludge process: OSA system. Water Sci Technol 1992;26(9-11):2477-80.

[72] Chudoba P, Morel A, Capdeville B. The case of both energetic uncoupling and metabolic selection of microorganisms in the OSA activated sludge system. Environ Technol 1992;13:761-70.

[73] Saby S, Djafer M, Chen GH. Effect of low ORP in anoxic sludge zone on excess sludge production in oxic-settlinganoxic activated sludge process. Water Res 2003; 37(1):11-20.

[74] Chen GH, Yip WK, Mo HK, Liu Y. Effect of sludge fasting/feasting on growth of activated sludge cultures. Water Res 2001;35(4):1029-37.

[75] Chen GH, An KJ, Saby S, Brois E, Djafer M. Possible cause of excess sludge reduction in an oxic-settlinganaerobic activated sludge process (OSA process). Water Res 2003;37(16):3855-66. 
[76] van Loosdrecht MCM, Henze M. Maintenance, endogeneous respiration, lysis, decay and predation. Water Sci Technol 1999;39(1):107-17.

[77] Low EW, Chase HA. The effect of maintenance energy requirements on biomass production during wastewater treatment. Water Res 1999;33(3):847-53.

[78] Chaize S, Huyard A. Membrane bioreactor on domestic wastewater treatment sludge production and modelling approach. Water Sci Technol 1991;23:1591-600.

[79] Cicek N, Macomber J, Davel J, Suidan MT, Audic J, Genestet P. Effect of solids retention time on the performance and biological characteristics of a membrane bioreactor. Water Sci Technol 2001;43(11):43-50.

[80] Muller EB, Stouthamer AH, van Verseveld HW, Eikelboom DH. Aerobic domestic waste water treatment in a pilot plant with complete sludge retention by cross-flow filtration. Water Res 1995;29(4):1179-89.

[81] Wagner J, Rosenwinkel KH. Sludge production in membrane bioreactors under different conditions. Water Sci Technol 2000;41(10-11):251-8.

[82] Rosenberger S, Kraume M, Szewzyk U. Sludge free management of membrane bioreactors. The 2nd Symposium on Membrane Bioreactor for Wastewater Treatment, 2 June 1999, the School of Water Sciences, Cranfield University, UK, 1999.

[83] Rosenberger S, Witzig R, Manz W, Szewzyk U, Kraume M. Operation of different membrane bioreactors: experimental results and physiological state of the microgrganisms. Water Sci Technol 2000;41(10-11): 269-77.

[84] Rosenberger S, Kruger U, Witzig R, Manz W, Szewzyk U, Kraume M. Performance of a bioreactor with submerged membranes for aerobic treatment of municipal wastewater. Water Res 2002;36(2):413-20.

[85] Witzig R, Manz W, Rosenberger S, Kruger U, Kraume M, Szewzyk U. Microbiological aspects of a bioreactor with submerged membranes for aerobic treatment of municipal wastewater. Water Res 2002;36(2):394-402.

[86] Visvanathan C, Aim RB, Parameshwaran K. Membrane separation bioreactors for wastewater treatment. Crit Rev Environ Sci Technol 2000;30(1):1-48.

[87] Churchouse S, Wildgoose D. Membrane bioreactor hit the big time - from lab to full-scale application. The 2nd Symposium on Membrane Bioreactors for Wastewater Treatment, 2 June 1999, Cranfield University, UK.

[88] Eikelboom DH. Extra toepassingsmogelijkheden voor protozoa en metazoa bij de zuivering van afvalwater. TNO-rapport no. R88/286, The Netherlands, 1988.

[89] Eikelboom DH. Process control of activated sludge plants by microscopic investigation. UK: IWA Publishing; 2000. p. 85-102.

[90] Ratsak CH, Kooi BW, van Verseveld HW. Biomass reduction and mineralization increase due to the ciliate Tetrahymena Pyriformis grazing on the bacterium Pseudomonas Fluorescens. Water Sci Technol 1994;29(7): 119-28.

[91] Welander T, Lee NM. Minimization of sludge production in aerobic treatment by use of predators. The Second International Symposium on Environmental Biotechnology, 4-6 July 1994, Brighton, UK, 1994.
[92] Lee NM, Welander T. Reducing sludge production in aerobic wastewater treatment through manipulation of the ecosystem. Water Res 1996;30(8):1781-90.

[93] Lee NM, Welander T. Use of protozoa and metazoa for decreasing sludge production in aerobic wastewater treatment. Biotechnol Lett 1996;18(4):429-34.

[94] Ghyoot W. Membrane-assisted bioreactor for anaerobic sludge digestion and low sludge production in aerobic wastewater treatment. PhD thesis. Unversity of Gent, Belgium, 1998.

[95] Ghyoot W, Verstraete W. Reduced sludge production in a two-stage membrane-assisted bioreactor. Water Res 2000;34(1):205-15.

[96] Lapinski J, Tunnacliffe A. Reduction of suspended biomass in municipal wastewater using bdelloid rotifers. Water Res 2003;37(9):2027-34.

[97] Ratsak CH, Kooijman SALM, Kooi BW. Modelling the growth of an oligochaete on activated sludge. Water Res 1993;27(5):739-47.

[98] Rensink JH, Rulkens WH. Using metazoa to reduce sludge production. Water Sci Technol 1997;36(11): 171-9.

[99] Learner MA. The distribution and ecology of the Naididae (Oligochaeta) which inhabit the filter-beds of sewage-works in Britain. Water Res 1979;13:1291-9.

[100] Ratsak CH. Grazer induced sludge reduction in wastewater treatment. $\mathrm{PhD}$ thesis, Vrije University, The Netherlands, 1994.

[101] Ratsak CH. Effects of Nais elinguis on the performance of an activated sludge plant. Hydrobiologia 2001; 463:217-22.

[102] Rensink JH, Corstanje R, van der Pal JH. A new approach to sludge reduction by metazoa. 10th European Sewage and Reuse Symposium, IFAT 1996, Munchen, 1996. p. 339-64.

[103] Janssen PMJ, Rulkens WH, Rensink JH, van der Poest HF. The potential for metazoa in biological wastewater treatment. WQI, September/October, 1998. p. 25-27.

[104] Zhang S. Polluted water treatment by the combining processes of membrane separation and biodegradation. $\mathrm{PhD}$ thesis, Research Centre for Eco-Environmental Sciences, Chinese Academy of Sciences, China, 2000.

[105] Eikelboom DH, Borger AR, van Houten RT. Reductie zuiveringsslib door borstelwormen. Fase 1: Laboratoriumonderzoek. TNO-rapport, The Netherlands, 2001.

[106] Wei YS, Van Houten RT, Borger AR, Eikelboom DH, Fan YB. Comparison performances of membrane bioreactor (MBR) and conventional activated sludge (CAS) processes on sludge reduction induced by Oligochaete. Environ Sci and Technol 2003;37(14):3171-80.

[107] Lee NM, Welander T. Influence of predator in nitrification in aerobic biofilm. Water Sci Technol 1994;29(7): 355-63.

[108] Luxmy BS, Kubo T, Yamamoto K. Sludge reduction potential of metazoa in membrane bioreactors. Water Sci Technol 2001;44(10):197-202.

[109] Adham S, Merlo RP, Gagliardo P. Membrane bioreactor for water reclamation: phase II. Desalination Research and Development Program Report No. 60, US Department of Interior, Water Treatment Engineering \& Research Group, 2000. 